\title{
ANALISIS KESALAHAN SISWA SMP DALAM MENYELESAIKAN SOAL TIMSS-LIKE DOMAIN DATA DAN PELUANG
}

\author{
Anisha Dwi Rahmawati \\ Jurusan Matematika, FMIPA, Universitas Negeri Surabaya \\ $e$-mail: anisharahmawati@mhs.unesa.ac.id
}

\begin{abstract}
Abstrak
Peringkat Indonesia relatif sangat rendah dibandingkan negara-negara Asia Tenggara lain yang ikut serta dalam TIMSS. Dari hasil peringkat TIMSS siswa Indonesia yang rendah ini, diketahui masih banyak kesalahan-kesalahan yang dilakukan oleh siswa. Salah satu upaya untuk menyelesaikan masalah ini adalah dengan mencari tahu letak kesalahan yang kerap dilakukan oleh siswa serta faktor penyebab siswa melakukan kesalahan tersebut. Dalam penelitian ini, metode yang digunakan adalah metode deskriptif yang bertujuan untuk mendeskripsikan kesalahan beserta faktor penyebab siswa melakukan kesalahan dalam menyelesaikan soal TIMSS-like pada domain data dan peluang. Subjek penelitian ini adalah 3 dari 19 siswa Lembaga Bimbingan Belajar (LBB) Primagama Sukodono kelas IX SMP yang dipilih berdasarkan banyaknya kesalahan dan variasi jenis kesalahan yang dilakukan saat tes tulis. Hasil penelitian memperlihatkan bahwa dalam menyelesaikan soal TIMSS-like domain data dan peluang, siswa yang melakukan kesalahan memahami soal sebesar 22,1\%, kesalahan transformasi soal sebesar $9,47 \%$ dan kesalahan keterampilan proses sebesar 4,21\%. Penyebab siswa melakukan kesalahan tersebut adalah siswa kurang teliti dalam membaca soal, tidak memahami maksud soal, salah dalam memilih cara penyelesaian, serta kurang latihan soal.
\end{abstract}

Kata Kunci: analisis kesalahan, soal TIMSS-like data dan peluang.

\section{Abstract}

Indonesia's position is relatively very low compared to other Southeast Asian countries participating in TIMSS. From the results of the TIMSS ranking of Indonesian students is low, it is known there are still many mistakes made by students. One effort to solve this problem is to find out where the location of errors that are often made by students and the factors causing students make these errors. In this study, the method used is a descriptive method that aims to describe the types and factors of student error in solving TIMSS-like domain Data and Chance problems. The subjects of this study were 3 out of 19 Lembaga Bimbingan Belajar (LBB) Primagama Sukodono students in class IX SMP selected based on the number of errors and variations in the types of errors made during the written test. The results showed that in solving TIMSS-like domain data and chance problems, students made errors in understanding the questions was $22.1 \%$, errors in transforming was $9.47 \%$ and errors in process skills was $4.21 \%$. The reason students make these errors is students are not careful in reading the questions, do not understand the purpose of the question, wrong in choosing a solution and lack of practice questions.

Keywords: error analysis, TIMSS-like data and chance problems.

\section{PENDAHULUAN}

Trend in International Mathematics and Science Study (TIMSS) adalah kajian internasional untuk mengukur kemampuan siswa. Studi tersebut bertujuan untuk mengkaji kurikulum yang digunakan setiap negara beserta penerapan dan penerimaan siswa khususnya pada bidang matematika dan sains. Program TIMSS dikelola oleh the International Association for the Evaluation of educational Achievement (IEA), yaitu organisasi internasional independen (Mullis dkk, 2009).

Setiap empat tahun sekali, IEA bekerja sama dengan institusi penelitian nasional dan agensi pemerintahan yang telah menyelenggarakan studi pencapaian antar negara sejak tahun 1959 (Mullis dkk, 2009).

Pada TIMSS, dasar penilaian capaian matematika dan sains dibagi ke dalam dua domain, yaitu isi dan kognitif. Dalam bidang matematika, domain isi yang menjadi fokus TIMSS meliputi bilangan, geometri, aljabar dan peluang, sedangkan domain kognitif dalam bidang matematika meliputi pengetahuan, penerapan, dan penalaran.

Target populasi dari TIMSS sendiri adalah siswa kelas 4 dan siswa kelas 8. Keikutsertaan Indonesia pada studi TIMSS dimulai tahun 1999 dengan target siswa kelas 8 SMP. Selanjutnya, tahun 2015 target populasinya menjadi kelas 4 SD. 
Pada partisipasi pertama kali tahun 1999, Indonesia menempati peringkat 34 dari 38 negara. Hasil kajian TIMSS 2003, Indonesia menempati peringkat 35 dari 46 negara peserta dengan nilai rata-rata 411 , sedangkan ratarata nilai internasional 467 (P4TK, 2011). Diketahui hasil teraktual, yaitu TIMSS 2015, Indonesia menempati peringkat 44 dari 49 negara (Nizam, 2016). Berikut adalah tabel hasil TIMSS Indonesia selama 4 periode terakhir.

Tabel 1. Hasil TIMSS Indonesia

\begin{tabular}{|l|c|l|l|l|}
\hline Th. & Peringkat & Peserta & $\begin{array}{l}\text { Rata-rata } \\
\text { Skor } \\
\text { Indonesia }\end{array}$ & $\begin{array}{l}\text { Rata-rata } \\
\text { Skor } \\
\text { Internasional }\end{array}$ \\
\hline 2003 & 35 & $\begin{array}{l}46 \\
\text { Negara }\end{array}$ & 411 & 467 \\
\hline 2007 & 36 & $\begin{array}{l}49 \\
\text { Negara }\end{array}$ & 397 & 500 \\
\hline 2011 & 38 & $\begin{array}{l}42 \\
\text { Negara }\end{array}$ & 386 & 500 \\
\hline 2015 & 44 & $\begin{array}{l}49 \\
\text { Negara }\end{array}$ & 397 & 500 \\
\hline
\end{tabular}

Dari Tabel 1, diketahui bahwa peringkat Indonesia pada TIMSS tahun 2003 adalah 35 dari 46 negara peserta. Tahun 2007 peringkat Indonesia adalah 36 dari 49 negara peserta, serta tahun 2011 peringkat Indonesia adalah 38 dari 42 negara peserta. Sedangkan tahun 2015 peringkat Indonesia adalah 44 dari 49 negara. Dari tabel tersebut dapat disimpulkan bahwa peringkat Indonesia dalam TIMSS setiap tahunnya semakin menurun.

Pada benchmark yang dibuat TIMSS, standar internasional untuk kategori mahir 625, tinggi 550, sedang 475, dan rendah 400. Dari benchmark tersebut, skor yang dicapai siswa Indonesia tersebut masuk pada kategori rendah, jauh dari kategori mahir (625), kategori yang ingin dicapai dalam kurikulum pendidikan matematika di sekolah. Dibandingkan negara-negara Asia Tenggara lain yang mengikuti TIMSS, posisi Indonesia tergolong rendah.

Dari hasil peringkat TIMSS siswa Indonesia yang rendah ini, diketahui masih banyak kesalahan-kesalahan yang dilakukan oleh siswa. Kesalahan adalah hal yang wajar dilakukan oleh siswa, termasuk dalam menyelesaikan soal matematika yang mayoritas dianggap sulit oleh siswa. Akan tetapi, apabila kesalahan ini tidak diperbaiki atau diketahui penyebabnya, maka siswa akan terus mengulang kesalahan-kesalahan yang pernah dilakukannya. Hal ini dapat menghambat siswa dalam belajar matematika itu sendiri yang berdampak pada capaian prestasi di internasional yang belum maksimal atau tertinggal dari negara lain. Salah satu upaya untuk menyelesaikan masalah ini adalah dengan mencari tahu letak kesalahan yang kerap dilakukan oleh siswa serta faktor penyebab siswa melakukan kesalahan tersebut.

Dalam penelitian ini, metode yang yang digunakan adalah metode deskriptif yang bertujuan untuk mendeskripsikan kesalahan serta faktor penyebab kesalahan yang dilakukan siswa SMP dalam menyelesaikan soal TIMSS-like domain data dan peluang.

Menurut Kamus Besar Bahasa Indonesia, analisis adalah penyelidikan terhadap suatu peristiwa (karangan, perbuatan, dan sebagainya) untuk mengetahui yang sebenarnya, sedangkan kesalahan adalah perihal yang menyimpang dari yang seharusnya. Berdasarkan kedua pengertian tersebut, analisis kesalahan berarti suatu upaya untuk menemukan, mengamati, dan mengklasifikasikan penyimpangan terhadap hal yang benar bersifat sistematis.

Analisis kesalahan Newman menurut White (2010) adalah analisis yang berfokus pada kesalahan siswa dalam membaca soal (reading errors), kesalahan memahami (comprehension errors), kesalahan transformasi (transformation errors), kesalahan keterampilan proses (process skills errors), dan kesalahan penulisan jawaban akhir (encoding errors).

Ada beberapa faktor yang menyebabkan siswa melakukan kesalahan dalam menyelesaikan soal matematika. Adapun faktor penyebab kesalahan secara umum menurut Priyani (2017) antara lain: siswa tidak memahami maksud soal, siswa tidak dapat menangkap informasi yang didapat dari soal, siswa salah dalam membuat model matematika dari informasi yang disajikan, kurangnya pemahaman siswa pada materi, tergesa-gesa dalam menyelesaikan soal, kurangnya latihan dalam menyelesaikan soal, dan tidak teliti dalam menyelesaikan soal.

Dasar penilaian prestasi matematika dan sains dalam TIMSS digolongkan ke dalam dua domain, yaitu domain isi dan domain kognitif dengan memperhatikan kurikulum yang berlaku di negara yang bersangkutan. Dalam TIMSS 2015 Assessment Framework disebutkan bahwa domain isi (konten) terdiri atas empat domain yaitu: bilangan, aljabar, geometri, serta data dan peluang. Domain kognitif terdiri atas tiga domain, yaitu pengetahuan (knowing), penerapan (applying), dan penalaran (reasoning).

Konten data dan peluang pada TIMSS memuat tiga topik, yaitu: karakteristik data serta menafsirkan data dan peluang. Berikut adalah indikator dalam soal konten data dan peluang menurut TIMSS 2015 Assesment Framework: (1) mengidentifikasi dan membandingkan karakteristik set data termasuk rata-rata, median, modus, jangkauan, dan bentuk distribusi (secara umum); (2) menghitung, menggunakan, atau menginterpretasikan rata-rata, median, modus, atau jangkauan untuk menyelesaikan masalah; (3) membaca data dari berbagai tampilan penyajian data; (4) menggunakan dan 
menginterpretasikan kumpulan data untuk menyelesaikan masalah; (5) mengidentifikasi dan menjelaskan pendekatan untuk mengatur dan menampilkan data yang dapat mengarah pada kesalahpahaman (misalnya: pengelompokan yang tidak sesuai dan skala yang mengecoh atau terdistorsi); (6) menilai peluang kejadian berbagai situasi (pasti, mungkin, tidak mungkin/mustahil); (7) menggunakan data, termasuk data eksperimental, untuk memperkirakan peluang kejadian di masa depan; dan (8) menentukan hasil peluang kejadian jika diberikan suatu proses yang dirancang secara acak.

Pada studi TIMSS, soal matematika yang digunakan berfokus untuk mengukur tingkatan kemampuan siswa. Tidak sekadar mengetahui fakta, prosedur atau konsep, tetapi juga menggunakan fakta, prosedur atau konsep tersebut untuk menyelesaikan problem yang sederhana hingga yang memerlukan penalaran tinggi.

Dalam penilitian ini, penulis menganalisis kesalahan siswa dalam menyelesaikan soal konten data dan peluang pada TIMSS dengan mengambil dua domain kognitif, yaitu domain penerapan (applying) dan domain penalaran (reasoning) karena kedua domain tersebut sesuai dengan proses dimensi kognitif dari revisi taksonomi bloom C3 dan $\mathrm{C} 4$, yaitu menerapkan dan menganalisis. Menerapkan adalah kegiatan melaksanakan atau menggunakan prosedur dalam suatu situasi tertentu, sedangkan menganalisis adalah kegiatan memisah informasi ke dalam bagian-bagian untuk mengeksplor pemahamanpemahaman dan hubungan-hubungan. Menganalisis adalah salah satu proses dimensi kognitif dari revisi taksonomi bloom yang masuk dalam berpikir tingkat tinggi (Anderson, 2001).

\section{METODE PENELITIAN}

Penelitian ini adalah penelitian deskriptif yang menggunakan pendekatan kualitatif. Tujuan dari penelitian ini adalah mendeskripsikan kesalahan beserta faktor penyebab siswa melakukan kesalahan dalam menyelesaikan soal TIMSS-like pada domain data dan peluang.

Penelitian ini memiliki rancangan penelitian sebagai berikut, langkah awal sebelum melakukan penelitian adalah menyusun instrumen penelitian yang akan digunakan. Selanjutnya peneliti melakukan tes tulis kepada siswa. Instrumen tes tulis ini berisikan 3 butir soal TIMSS-like domain data dan peluang yang belum pernah dikerjakan siswa sebelumnya. Tes ini dilakukan untuk mengetahui letak dan jenis kesalahan dari penyelesaian yang dilakukan siswa. Hasil analisis tes tulis ini digunakan untuk menentukan subjek penelitian. Lembaga Bimbingan Belajar (LBB) Primagama Sukodono dipilih peneliti sebagai lokasi penelitian dengan subjek yang digunakan dalam penelitian ini adalah siswa kelas IX yang berjumlah 19 siswa. Siswa kelas IX dipilih karena sudah mendapatkan pengajaran tentang materi data dan peluang, sehingga dianggap sudah mempunyai kemampuan untuk mengaplikasikan materi data dan peluang dalam menyelesaikan tes yang diberikan. Dari 19 siswa yang mengerjakan tes tulis soal TIMSS-like domain data dan pelung, di pilih 3 siswa sebagai subjek penelitian. Subjek penelitian dipilih berdasarkan dua kriteria, yaitu: 1) siswa dengan kesalahan terbanyak pada butir tes dan banyaknya indikator kesalahan; 2) variasi jenis kesalahan. Setelah subjek terpilih, maka dilakukan wawancara untuk menggali informasi yang belum diketahui dari tes tulis (faktor penyebab kesalahan yang dilakukan siswa). Pengumpulan data pada penelitian ini menggunakan teknik tes tertulis dan wawancara untuk mendapatkan data yang diperlukan dalam penelitian. Instrumen yang digunakan dalam pengumpulan data berupa tes tulis dan pedoman wawancara. Teknik analisis data yang digunakan pada penelitian ini ada tiga tahapan, yaitu: tahapan reduksi data, tahapan penyajian data, dan tahapan penarikan simpulan.

Dalam penelitian ini, peneliti menggunakan analisis kesalahan Newman antara lain: kesalahan membaca (Reading Errors), kesalahan memahami (Comprehension Errors), kesalahan transformasi (Transformation Errors), kesalahan keterampilan proses (Process Skill Errors) dan kesalahan penulisan jawaban akhir (Encoding Errors). Berikut adalah indikator jenis kesalahan menurut Newman yang di jelaskan pada Tabel 2.

Tabel 2. Indikator jenis kesalahan berdasarkan tahapan Newman

\begin{tabular}{|l|l|l|}
\hline No. & \multicolumn{1}{|c|}{ Jenis Kesalahan } & \multicolumn{1}{|c|}{ Indikator } \\
\hline K1 & $\begin{array}{l}\text { Kesalahan membaca } \\
\text { soal (reading errors) }\end{array}$ & $\begin{array}{l}\text { Siswa melakukan } \\
\text { keasalah pada saat } \\
\text { membaca soal. }\end{array}$ \\
\cline { 3 - 4 } & & $\begin{array}{l}\text { Siswa salah dalam } \\
\text { menggunakan } \\
\text { informasi yang ada } \\
\text { untuk menyelesaikan } \\
\text { soal. }\end{array}$ \\
\hline K2 & $\begin{array}{l}\text { Kesalahan memahami } \\
\text { soal (comprehension } \\
\text { errors) }\end{array}$ & $\begin{array}{l}\text { Siswa salah dalam } \\
\text { mengartikan informasi } \\
\text { pada soal. }\end{array}$ \\
\cline { 2 - 4 } & $\begin{array}{l}\text { Siswa tidak dapat } \\
\text { memproses informasi } \\
\text { yang ada pada soal. }\end{array}$ \\
\hline K3 & $\begin{array}{l}\text { Kesalahan } \\
\text { transformasi soal } \\
\text { transformation }\end{array}$ & $\begin{array}{l}\text { Siswa salah dalam } \\
\text { mengubah kalimat yang } \\
\text { ada pada soal menjadi }\end{array}$ \\
\hline
\end{tabular}




\begin{tabular}{|c|c|c|}
\hline & \multirow[t]{2}{*}{ errors) } & kalimat matematika. \\
\hline & & $\begin{array}{l}\text { Siswa salah dalam } \\
\text { merencanakan solusi. }\end{array}$ \\
\hline \multirow[t]{2}{*}{ K4 } & \multirow[t]{2}{*}{$\begin{array}{l}\text { Kesalahan } \\
\text { keterampilan proses } \\
\text { (prosess skill errors) }\end{array}$} & $\begin{array}{l}\text { Siswa salah dalam } \\
\text { memproses informasi } \\
\text { yang ada pada soal. }\end{array}$ \\
\hline & & $\begin{array}{l}\text { Siswa salah dalam } \\
\text { proses komputasi atau } \\
\text { proses perhitungan. }\end{array}$ \\
\hline \multirow[t]{2}{*}{ K5 } & \multirow[t]{2}{*}{$\begin{array}{l}\text { Kesalahan penulisan } \\
\text { jawaban akhir } \\
\text { (encoding errors) }\end{array}$} & $\begin{array}{l}\text { Siswa tidak menuliskan } \\
\text { jawaban akhir pada } \\
\text { lembar jawaban }\end{array}$ \\
\hline & & $\begin{array}{l}\text { Siswa tidak menuliskan } \\
\text { jawaban akhir pada } \\
\text { lembar jawaban }\end{array}$ \\
\hline
\end{tabular}

\section{HASIL DAN PEMBAHASAN}

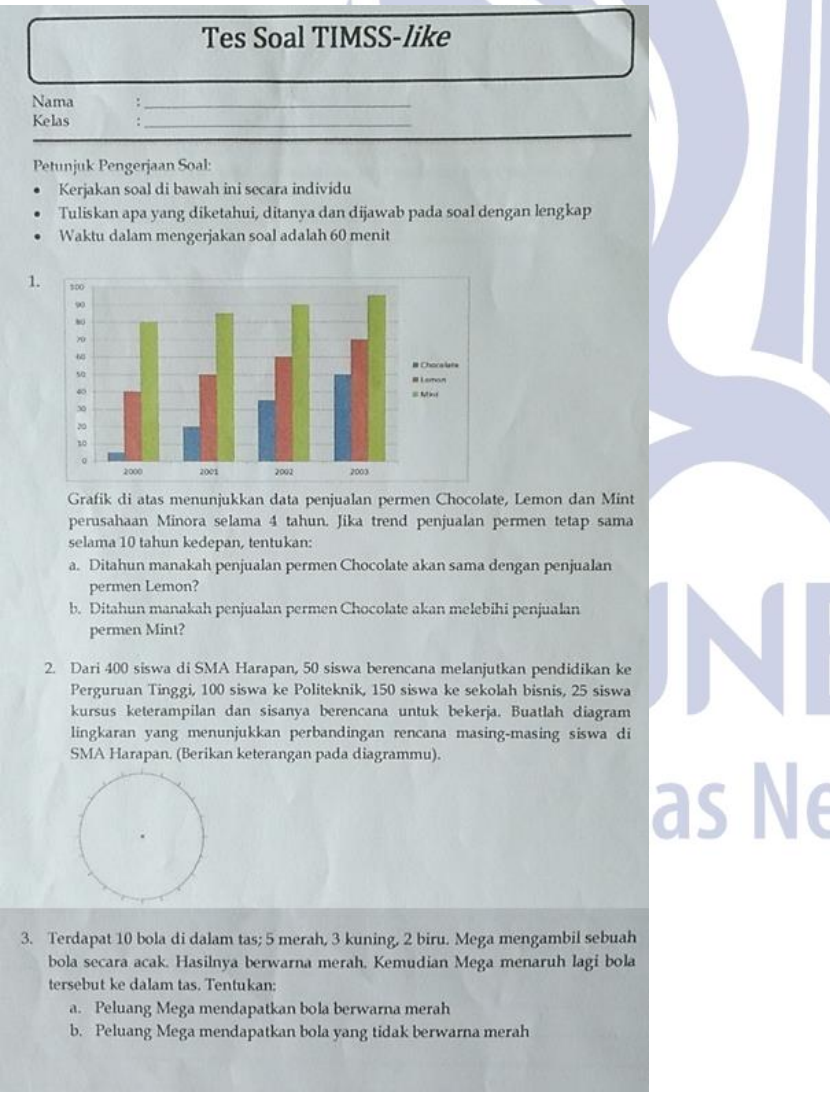

Gambar 1. Soal TIMSS-like domain data dan peluang

Hasil penelitian jenis kesalahan siswa SMP dalam menyelesaikan soal TIMSS-like domain data dan peluang disajikan pada tabel 3 berikut.
Tabel 3. Jenis Kesalahan Siswa dalam Menyelesaikan Soal TIMSS-like Domain Data dan Peluang

\begin{tabular}{|c|c|c|c|c|c|c|}
\hline \multirow{2}{*}{ No. } & \multirow{2}{*}{ Nama } & \multicolumn{5}{|c|}{ Nomor Soal } \\
\hline & & 1a & $1 \mathrm{~b}$ & 2 & $\mathbf{3 a}$ & $\mathbf{3 b}$ \\
\hline 1. & SADA & $\sqrt{ }$ & $\mathrm{K} 2$ & $\sqrt{ }$ & $\mathrm{K} 2$ & K2 \\
\hline 2. & RNS & $\mathrm{K} 2$ & - & K3 & K4 & K4 \\
\hline 3. & $\mathrm{AZ}$ & $\sqrt{ }$ & $\mathrm{K} 2$ & $\sqrt{ }$ & $\mathrm{K} 2$ & $\mathrm{~K} 2$ \\
\hline 4. & LAKP & - & - & K3 & & \\
\hline 5. & SPA & & & K3 & K4 & K4 \\
\hline 6. & RPD & $\mathrm{K} 2$ & K2 & $\sqrt{ }$ & $\sqrt{ }$ & $\sqrt{ }$ \\
\hline 7. & MAN & $\sqrt{ }$ & $\sqrt{ }$ & $\sqrt{ }$ & $\sqrt{ }$ & $\sqrt{ }$ \\
\hline 8. & SDA & $\sqrt{ }$ & $\sqrt{ }$ & $\sqrt{ }$ & $\sqrt{ }$ & $\sqrt{ }$ \\
\hline 9. & HAN & $\sqrt{ }$ & $\sqrt{ }$ & $\sqrt{ }$ & $\sqrt{ }$ & $\sqrt{ }$ \\
\hline 10. & RIC & $\mathrm{K} 2$ & $\sqrt{ }$ & $\sqrt{ }$ & $\sqrt{ }$ & $\sqrt{ }$ \\
\hline 11. & FDS & $\sqrt{ }$ & $\sqrt{ }$ & $\sqrt{ }$ & $\sqrt{ }$ & $\sqrt{ }$ \\
\hline 12. & $\mathrm{NN}$ & $\sqrt{ }$ & $\sqrt{ }$ & K2 & K2 & K2 \\
\hline 13. & MNU & $\sqrt{ }$ & $\sqrt{ }$ & K3 & $\sqrt{ }$ & $\sqrt{ }$ \\
\hline 14. & YSA & $\mathrm{K} 2$ & $\mathrm{~K} 2$ & & $\mathrm{~K} 2$ & $\mathrm{~K} 2$ \\
\hline 15. & ZTF & $\sqrt{ }$ & $\sqrt{ }$ & K3 & $\sqrt{ }$ & $\sqrt{ }$ \\
\hline 16. & $\mathrm{AZNH}$ & $\mathrm{K} 2$ & $\mathrm{~K} 2$ & K3 & $\sqrt{ }$ & $\sqrt{ }$ \\
\hline
\end{tabular}

Keterangan: $(\sqrt{ })=$ benar; $(-)=$ tidak diisi; $\mathbf{K 2}=$ kesalahan memahami soal; K3 = kesalahan transformasi soal; K4 = kesalahan keterampilan proses.

Berdasarkan Tabel 3, didapatkan hasil 56 soal diselesaikan dengan benar, 21 soal diselesaikan dengan kesalahan memahami soal, 9 soal dengan kesalahan transformasi, 4 soal diselesaikan dengan kesalahan keterampilan proses, serta 5 soal tidak diisi/tidak ada proses pengerjaan. Saat siswa tidak mengisi jawaban/ tidak menuliskan proses pengerjaannya, maka siswa dianggap tidak melakukan kesalahan karena siswa tidak menuliskan apapun pada lembar jawaban sehingga jawaban siswa tidak dianalisis lebih lanjut. Total kesalahan siswa dalam menyelesaikan soal TIMSS-like domain data dan peluang adalah 34 dari 95 soal yang dikerjakan oleh 19 siswa. Sehingga didapatkan hasil presentase sebagai berikut: $58,95 \%$ siswa menjawab dengan benar, $5,27 \%$ siswa tidak menjawab pertanyaan, dan $35,78 \%$ siswa melakukan kesalahan dalam menyelesaikan soal. Adapun persentase kesalahan siswa sebagai berikut: kesalahan memahami soal (comprehension errors) sebesar 22,1\%, kesalahan dalam mentransformasi (transformation errors) sebesar 9,47\%, dan kesalahan dalam keterampilan proses (process skill errors) sebesar $4,21 \%$.

Dari hasil analisis tes tulis dan pertimbangan tentor LBB, maka dipilih 3 siswa yang akan dijadikan subjek penelitian. Hasil analisis ketiga subjek penelitian tersebut dipaparkan sebagai berikut.

1. RNS merupakan subjek penelitian pertama (SP1). SP1 merupakan subjek penelitian yang melakukan kesalahan terbanyak. Untuk soal nomor 1a, SP1 melakukan kesalahan dalam memahami maksud soal. Untuk soal nomor 1b, SP1 tidak mengisi jawaban, 
sehingga siswa dianggap tidak melakukan kesalahan karena tidak ada yang bisa dianalisis lebih lanjut. Pada soal nomor 2, SP1 melakukan kesalahan dalam mentransformasi soal. Sedangkan pada soal nomor 3a dan nomor 3b, SP1 melakukan kesalahan keterampilan proses.

2. SPA merupakan subjek penelitian kedua (SP2). Untuk soal nomor 1a dan 1b, SP2 menjawab dengan benar. Pada soal nomor 2, SP2 melakukan kesalahan dalam mentransformasi. Untuk soal nomor 3a, SP2 melakukan kesalahan dalam keterampilan proses. Untuk soal nomor 3b, SP2 melakukan kesalahan dalam keterampilan proses.

3. YSA merupakan subjek penelitian ketiga (SP3). Dalam menyeleseaikan soal nomor 1a, SP3 melakukan kesalahan memahami soal. Untuk soal nomor 1b, SP3 melakukan kesalahan memahami soal. Pada soal nomor 2, SP3 menjawab dengan benar. Pada soal nomor 3a, SP3 melakukan kesalahan memahami soal. Untuk soal nomor 3b, SP3 melakukan kesalahan memahami soal.

\begin{tabular}{|c|c|c|}
\hline 1. & \multicolumn{2}{|c|}{ a.) Chocdate-trap th +15} \\
\hline$\square$ & \multicolumn{2}{|c|}{ Lemon trap th +10} \\
\hline$\square$ & \multicolumn{2}{|c|}{ Chocolate / Lemon } \\
\hline$\square$ & 5 & 40 \\
\hline$\square$ & 20 & so \\
\hline$\square$ & $3 k$ & 60 \\
\hline$\square$ & 50 & 70 \\
\hline$\square$ & 65 & 80 \\
\hline$\square$ & 6th & 90 \\
\hline$\square$ & 7th & 100 \\
\hline$\square$ & Coth & 110 \\
\hline$\square$ & 9 th & 120 \\
\hline$\square$ & 10th. $\quad 140$ & 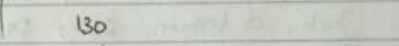 \\
\hline 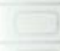 & Jadi, ditahun 2008 & 8 penjualan permen chocdate \\
\hline$\square$ & dan lemon sama. & \\
\hline$\square$ & b) Chocolate >mint. & \\
\hline$\square$ & +15 & \\
\hline 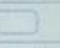 & Chocolate & mint \\
\hline$\square$ & Ith & 80 \\
\hline 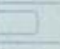 & 2 th & 8s \\
\hline 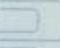 & 3th & 90 \\
\hline$\square$ & 50 & gs \\
\hline 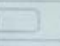 & 5th & 100 \\
\hline 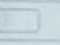 & bth & 105 \\
\hline 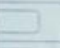 & 7th & 110 \\
\hline$\square$ & 8th & 115 \\
\hline 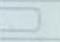 & 9th & 120 \\
\hline Q & 10 th 140 & 125 \\
\hline$\square$ & Jadi, ditahun 2009 & 1) Penjualan chocolate lebih \\
\hline Q & besar dart perjuolan & mint. \\
\hline
\end{tabular}

Gambar 2. Hasil jawaban SP3 nomor 1a san 1b

Berdasarkan gambar di atas (Gambar 2), SP3 salah dalam menyelesaikan soal nomor $1 \mathrm{a}$ dan $1 \mathrm{~b}$.
SP3 salah dalam memahami informasi penting dalam soal yaitu informasi tahun penjualan. Dalam gambar tersebut terlihat bahwa SP3 salah menuliskan informasi tahun yang diketahui, seharusnya tahun ke 8 adalah tahun 2007 dan tahun ke 9 adalah tahun 2008 dikarenakan tahun pertama pada tabel dimulai pada tahun 2000. SP3 mengira bahwa tahun ke 8 adalah tahun 2008 dan tahun ke 9 adalah tahun 2009.

Berikut cuplikan wawancara dengan SP3 ketika ditanya mengenai alasan dalam menuliskan hasil pada lembar jawaban:

P : Kenapa kamu menuliskan tahun 2008 dan 2009 dek?

SP3 : Iya itu hasil jawabannya mbak.

$\mathrm{P}$ : Bagaimana caranya kamu mendapatkan tahun 2008 dan 2009?

SP3 : Ya kan saya tinggal mengurutkan hasil dan tahun dari penjualan permen chocolate, lemon dan mint mbak.

$\mathrm{P}$ : Apakah kamu yakin dengan jawabanmu?

SP3: Iya mbak, disitu kan tahun ke-8 penjualan permen chocolate dan lemon sama, tahun ke-9 penjualan permen chocolate lebih besar dari penjualan mint.

P : Coba kamu baca soal dan teliti jawabanmu. Apakah yang diminta soal dan jawabanmu sudah benar?

SP3 : Loalah, iya mbak. Saya salah nulisnya. Saya kira tahun ke berapa, makanya saya tulis 2008 dan 2009.

P : Kenapa kamu kira yang ditanyakan tahun ke berapa? Kenapa kamu juga nulisnya tahun ke-8 itu 2008?

SP3 : Saya buru-buru mbak. Saya kira tahunnya sudah urut, jadi tahun ke-1 sama dengan tahun 2001. Saya nggak ngecheck lagi hasil pertanyaan dan jawabannya. Jadi ya langsung saya tulis begitu.

Berdasarkan hasil wawancara, SP3 melakukan kesalahan memahami soal dikarenakan tidak teliti dalam membaca soal. SP3 tergesa-gesa pada saat membaca soal, sehingga dia salah dalam membaca informasi penting pada soal yaitu tahun yang ditanyakan pada soal. SP3 mengetahui dengan jelas langkah penyelesaian soal seperti apa, hanya saja ia salah dalam membaca infornasi soal sehingga hasil akhir tetap salah. 


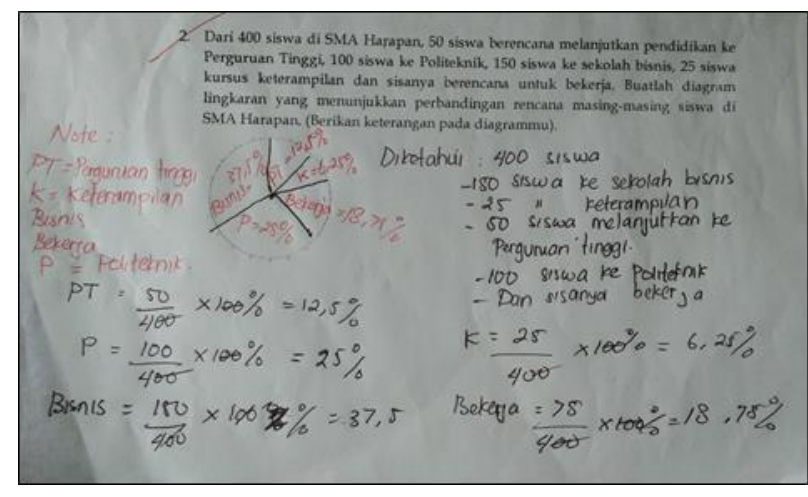

Gambar 3. Hasil jawaban SP2 nomor 2

Berdasarkan gambar 3 diatas, SP2 melakukan kesalahan dalam mentransformasi pada soal nomor 2 . Pada soal nomer 2, siswa diminta untuk menyajikan data dalam bentuk diagram lingkaran. SP2 menyelesaikan soal dengan cara mengubah informasi yang diketahui ke dalam presentase dan langsung mengubahnya menjadi bentuk diagram lingkaran. Dalam hasil penyelesaian SP2, terlihat bahwa diagram lingkaran yang dibuat tidak diubah kedalam bentuk derajat dan bentuknya pun tidak presisi. Sehingga hal tersebut membuat SP2 melakukan kesalahan dalam proses transformasi.

Berikut cuplikan wawancara dengan SP2 ketika ditanya mengenai alasan dalam menuliskan hasil pada lembar jawaban:

$\mathrm{P}$ : Coba cermati informasi yang ada pada soal nomor 2. Apa yang diketahui pada soal dek?

SP2: Siswa SMA Harapan berjumlah 400 orang. 50 siswa akan ke perguruan tinggi, 100 ke Politeknik, 150 ke sekolah bisnis, 25 kursus keterampilan dan sisanya bekerja mbak.

$\mathrm{P} \quad$ : Lalu apa yang diminta soal?

SP2 : Membuat diagram lingkaran yang menunjukkan perbandingan rencana masing-masing siswa di SMA Harapan mbak.

$\mathrm{P} \quad$ : Bagaimana cara kamu menyelesaikannya?

SP2: Saya ubah masing-masing ke bentuk persen mbak, kemudian langsung saya masukkan ke diagram lingkaran.

$\mathrm{P} \quad$ : Apakah gambarmu benar-benar sesuai dengan perbandingan data siswa?

SP2 : Saya nggak yakin sih mbak.

$\mathrm{P}$ : Bagaimana menuliskan data pada diagram lingkaran? Apakah benar seperti itu? Atau kamu lupa sesuatu? Adakah cara yang membuat data perbandingan siswa bisa sesuai dengan lingkaran?

SP2 : Loh iya, saya lupa mengubahnya ke bentuk derajat mbak. Seharusnya saya ubah ke bentuk derajat dulu sebelum memasukan ke diagram lingkaran biar gambarnya sesuai dengan data.

\section{P : Kenapa kamu nggak melakukannya seperti itu?}

SP2 : Saya lupa dan kurang teliti mbak.

Berdasarkan hasil wawancara, SP2 mampu memahami maksud yang ditanyakan pada soal. Akan tetapi SP2 kurang teliti dalam menyajikan data pada diagram lingkaran. SP2 salah dalam mentransformasikan data pada diagram lingkaran, yang seharusnya data diubah kedalam bentuk derajat. SP2 hanya menuliskan data dalam bentuk presentase yang kemudian dimasukkan kedalam diagram lingkaran, sehingga penyajian data pada bentuk diagram lingkaran kurang tepat. Alasan SP2 melakukan kesalahan tersebut adalah dikarenakan ia lupa dan kurang teliti dalam mengerjakan soal nomor2.

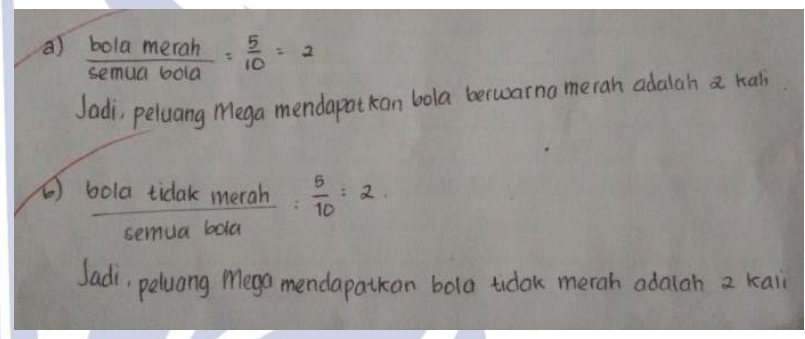

Gambar 4. Hasil jawaban SP1 nomor 3a dan 3b

Berdasarkan gambar 4, SP1 melakukan kesalahan keterampilan proses pada soal nomor $3 \mathrm{a}$ dan $3 \mathrm{~b}$. Pada soal 3a, ditanyakan peluang terambilnya bola warna merah. Pada penulisan informasi dan rumus, SP1 sudah benar, yaitu diketahui bahwa terdapat 5 bola merah dan jumlah semua bola adalah 10 . Sehingga untuk memperoleh peluang terambilnya bola merah adalah bola merah per semua bola $=5 / 10$. Akan tetapi SP1 salah melakukan proses perhitungan peluang, terlihat bahwa SP1 menuliskan peluang $5 / 10=2$, yang seharunya adalah $1 / 2$. Begitupun soal nomer $3 b, S p 1$ salah dalam proses perhitungan peluang juga, yang seharunya adalah $5 / 10=$ $1 / 2$ bukan 2 .

Berikut cuplikan wawancara dengan SP1 ketika ditanya mengenai alasan dalam menuliskan hasil pada lembar jawaban:

$\mathrm{P}$ : Berdasarkan soal nomor 3, apa yang kamu ketahui dek?

SP1 : Ada bola di tas. 5 merah, 3 kuning, 2 biru.

$\mathrm{P}$ : Apa yang ditanyakan pada soal?

SP1 : Peluang Mega mendapakan bola warna merah dan peluang Mega mendapatkan bola selain warna merah mbak.

$\mathrm{P} \quad$ : Lalu bagaimana kamu menyelesaikan soal tersebut? 
SP1 : Untuk peluang terambilnya bola merah sama dengan jumlah bola merah per jumlah seluruh bola di dalam tas. Jadi hasilnya 5/10 atau 1/2. Kemudian untuk peluang terambilnya bola selain yang warna merah, jumlah bola selain warna merah per jumlah seluruh bola di dalam tas, yaitu 5/ 10 atau 1/2.

$\mathrm{P}$ : Apakah menurutmu jawabanmu sudah benar?

SP1 : Loh saya nulis 2 toh? Saya pikir saya sudah nulis $1 / 2$ mbak.

$\mathrm{P} \quad$ : Kenapa kamu menuliskan 2 pada hasil akhir?

SP1 : Saya nggak tau mbak, saya pikir saya sudah nulis 1/2. Mungkin saya ngeblank mbak pas ngerjainnya. Mungkin saya mikirnya 10 dibagi 5, mkanya hasilnya 2 .

$\mathrm{P}$ : Terus kenapa di kesimpulan kamu juga nulis 2 ?

SP1: Saya nggak ngecheck lagi jawabannya mbak, jadi ya saya ikut jawabannya di atasnya. Karena pekerjaan di atas saya nulis 2 , makanya kesimpulannya saya nulis 2 juga. Saya kurang teliti.

Berdasarkan hasil wawancara, kesalahan keterampilan proses yang dilakukan SP1 dikarenakan ia kurang teliti dalam proses komputasi atau perhitungan. SP1 mengetahui informasi pada soal serta cara penyelesaian soal tersebut, akan tetapi ia tergesa-gesa dalam menyelesaikannya sehingga ia kurang teliti dalam proses perhitungan yang menyebabkan ia salah dalam menyelesaikan soal nomor $3 a$ dan $3 b$.

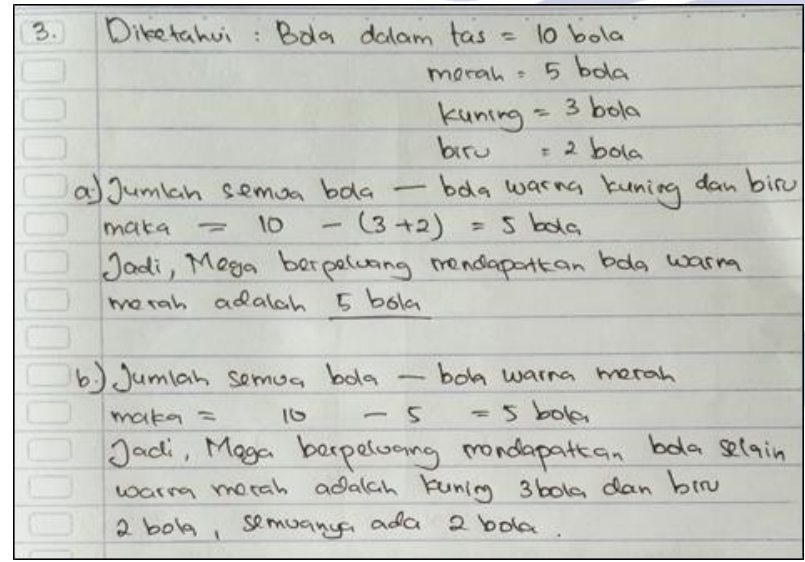

Gambar 5. Hasil jawaban SP3 nomor 3a dan 3b

Berdasarkam gambar 5, SP3 melakukan kesalahan memahami soal pada soal nomor 3a dan 3b. SP3 menuliskan apa yang diketahui pada soal, tetapi ia tidak mengerti maksud yang ditanyakan dari soal tersebut. Terlihat pada jawaban 3a, dalam memperoleh peluang mendapatkan bola warna merah, SP3 hanya melakukan operasi pengurangan pada informasi yang diketahui yaitu mengurangi jumlah seluruh bola dengan jumlah bola yang tidak berwaran merah. Sehingga diperoleh peluang terambilnya bola merah adalah $10-5=5$. Hal tersebut juga dilakukan SP3 dalam menyelesaikan soal 3b, yaitu dalam mendapatkan peluang mendapatkan bola selain warna merah, SP3 hanya melakukan pengurangan jumlah seluruh bola dengan jumlah bola berwarna merah. Sehingga didapatkan jawaban untuk soal 3 b adalah $10-5$ $=5$.

Berikut cuplikan wawancara dengan SP3 ketika ditanya mengenai alasan dalam menuliskan hasil pada lembar jawaban:

P : Coba kamu baca lagi soal nomor 3 . Informasi apa yang kamu dapatkan dek?

SP3 : Diketahui 10 bola di dalam tas, 5 merah, 3 biru, 2 kuning. Yang ditanyakan peluang mendapatkan bola warna merah dan peluang mendapatkan bola selain warna merah mbak.

$\mathrm{P}$ : Bagaimana menentukan peluang suatu kejadian?

SP3 : Saya nggak tau mbak.

$\mathrm{P} \quad$ : Terus kenapa kamu bisa menjawab seperti itu?

SP3: Saya hanya mengira-ngira jawabannya seperti itu mbak. Saya nggak bisa ngerjain soalnya.

$\mathrm{P}$ : Kenapa kamu tidak bisa mengerjakan soal peluang? Kan materi ini sudah pernah diajarkan di kelas 8 .

SP3 : Saya lupa mbak. Saya tidak belajar tadi malam. Saya kurang latihan juga.

Berdasarkan hasil wawancara, diketahui kesalahan memahami yang dilakukan SP3 dikarenakan ia tidak memahami materi dari soal tersebut. SP3 tidak memahami konsep peluang yang diajarkan di kelas 8 , serta ia tidak belajar sebelum tes tulis ini diadakan.

Dari seluruh hasil jawaban yang telah dikerjakan siswa pada saat tes tulis, ditemukan beberapa kesalahan, antara lain: kesalahan memahami soal, kesalahan transformasi dan kesalahan keterampilan proses. Pada saat melakukan kesalahan memahami soal, siswa seringkali tidak mengerti maksud yang ditanyakan dalam soal. Ada juga siswa yang kurang tepat/salah dalam menuliskan informasi (yang ditanyakan) pada soal. Pada kesalahan transformasi, banyak siswa yang telah mengerti maksud soal (yang ditanyakan). Akan tetapi, siswa salah dalam menggunakan cara atau rumus dalam mengerjakan soal, sehingga meskipun pengerjaannya benar, jawaban siswa tetap salah. Pada kesalahan keterampilan proses, meskipun siswa tepat dalam menentukan cara pengerjaan, tetapi pada tahap selanjutnya siswa melakukan kesalahan saat melakukan pengoperasian. Ada pula siswa yang salah memasukkan nilai yang sudah diketahui dan ada pula siswa yang salah dalam melakukan operasi hitung.

Siswa melakukan kesalahan-kesalahan tersebut bukan tanpa alasan. Setelah dilakukan wawancara terhadap 3 subjek penelitian, didapatkan hasil sebagai berikut. 
1. Penyebab kesalahan memahami soal

- Siswa tidak teliti pada saat membaca soal.

- Siswa kurang memahami maksud dari soal karena mereka tidak belajar sebelum tes tulis ini diadakan.

2. Penyebab kesalahan transformasi

- Siswa tidak memahami maksud soal.

- Siswa tidak teliti dalam pengerjaan.

- Siswa salah dalam memilih cara penyelesaian.

3. Penyebab kesalahan keterampilan proses

- Siswa kurang teliti dalam proses pengerjaan.

- Siswa kurang latihan soal.

\section{PENUTUP}

\section{Simpulan}

Dari hasil penelitian yang dilakukan tentang analisis kesalahan siswa SMP dalam menyelesaikan soal TIMSSlike domain data dan peluang didapatkan hasil sebagai berikut:

1. Siswa paling banyak melakukan kesalahan dalam memahami soal, yaitu sebesar 22,1\%. Penyebab utamanya adalah siswa kurang teliti dalam membaca soal dan kurang memahami maksud dari soal.

2. Kesalahan mentransformasi soal dilakukan siswa sebesar 9,47\%. Penyebabnya adalah siswa tidak memahami maksud dari soal, kurang teliti dalam mengerjakan, dan salah dalam memilih cara pengerjaan.

3. Kesalahan keterampilan proses dilakukan siswa sebesar 4,21\%. Penyebabnya adalah siswa kurang teliti dalam proses pengerjaan dan kurang latihan soal.

\section{Saran}

Beberapa saran yang dapat diberikan oleh peneliti terkait dengan hasil penelitian dijelaskan sebagai berikut.

1. Untuk melatih siswa dalam menyelesaikan soal TIMSS yang melibatkan higher order thinking skills sebaiknya diberikan beberapa latihan soal lagi agar siswa dapat menyelesaikan soal dengan benar secara mandiri.

2. Perlu dilakukan penelitian lebih lanjut mengenai kesalahan siswa dalam menyelesaikan soal TIMSSlike domain data dan peluang yang melibatkan Higher Order Thinking Skills (HOTS) sebagai pengembangan penelitian ini.

3. Bagi peneliti lain yang ingin melakukan penelitian sejenis dengan penelitian ini, sebaiknya memperhatikan waktu yang tepat dalam mengambil data. Penelitian ini diambil saat bulan Ramadhan dan pada saat pandemik Covid-19, sehingga wawancara yang dilakukan kurang komunikatif.disusun berdasarkan temuan penelitian yang telah dibahas. Saran dapat mengacu pada tindakan praktis, pengembangan teori baru, dan/atau penelitian lanjutan.

\section{DAFTAR PUSTAKA}

Anderson, Lorin W. \& Krathwohl, David R. 2001. A Taxonomy for Learning, Teaching and Assessing: a Revision of Bloom's Taxonomy. New York: Longman Publishing.

Badan Pengembangan dan Pembinaan Bahasa. 2020. Kamus Besar Bahasa Indonesia. Online.https://kbbi.kemdikbud.go.id/ diakses pada 17 Januari 2020.

Clements, M.A. \& Ellerton, N.F. 1996. The Newman Procedure for Analysing Errors on Written Mathematical Tasks. (Online). http://www.compasstech.com.au/ARNOLD/PA GES/newman.htm diakses 15 Januari 2020

International Association for the Evaluation of Educational Achievement. 2013. TIMSS 2015 Assessment Framework. United States: TIMSS and PIRLS International Study Center.

Kementrian Pendidikan Nasional. 2011. Instrumen Penilaian Hasil Belajar Matematika SMP: Belajar dari PISA dan TIMSS. Yogyakarta: P4TK.

Miles, B. M. d. M. H. 1992. Analisis Data Kualitatif Buku Sumber Tentang Metode-metode Baru. Jakarta: UIP.

Moleong. 2009. Metodologi Kualitatif. Edisi Revisi. Bandung: PT Remaja Rosdakarya.

Mullis, I.V.V., Martin, M.O., Ruddock, G.J., O’Sullivan, C.Y. \& Preuschoff, C. 2009. TIMSS 2011 Assesment Frameworks. Amsterdam: International Association for the Evaluation of Educational Achievement (IEA).

Nizam. 2016. Ringkasan Hasil-hasil Asesmen Belajar Dari hasil UN, PISA, TIMSS, INAP. Jakarta: Pusat Penilaian Pendidikan Badan Penelitian dan Pengembangan Kementrian Pendidikan dan Kebudayaan.

Priyani, Harselly A. 2017. Analisis Kesalahan Siswa dalam Menyelesaikan Soal Konten Bilangan pada TIMSS. Skripsi tidak dipublikasikan. Surabaya: UNESA.

Rohmani, M. B. Nur. 2017. Analisis Kesalahan Siswa dalam Mengerjakan Soal Mirip TIMSS Berdasarkan Distraktor dan Teori Kesalahan Newman. Skripsi tidak dipublikasikan. Yogyakarta: Universitas Negeri Yogyakarta.

Takaria, J. 2015. Peningkatan Literasi Statistis, Representasi Matematis, dan Self Concept Mahasiswa Calon Guru Sekolah Dasar melalui 
Model Collaborative Problem Solving. Doctoral dissertation.UPI.

White, A. L. 2010. Numeracy, Literacy and Newman's Error Analysis. Journal of Science and Mathematics Education in Southeast Asia, 33(2), pp. 129-148.

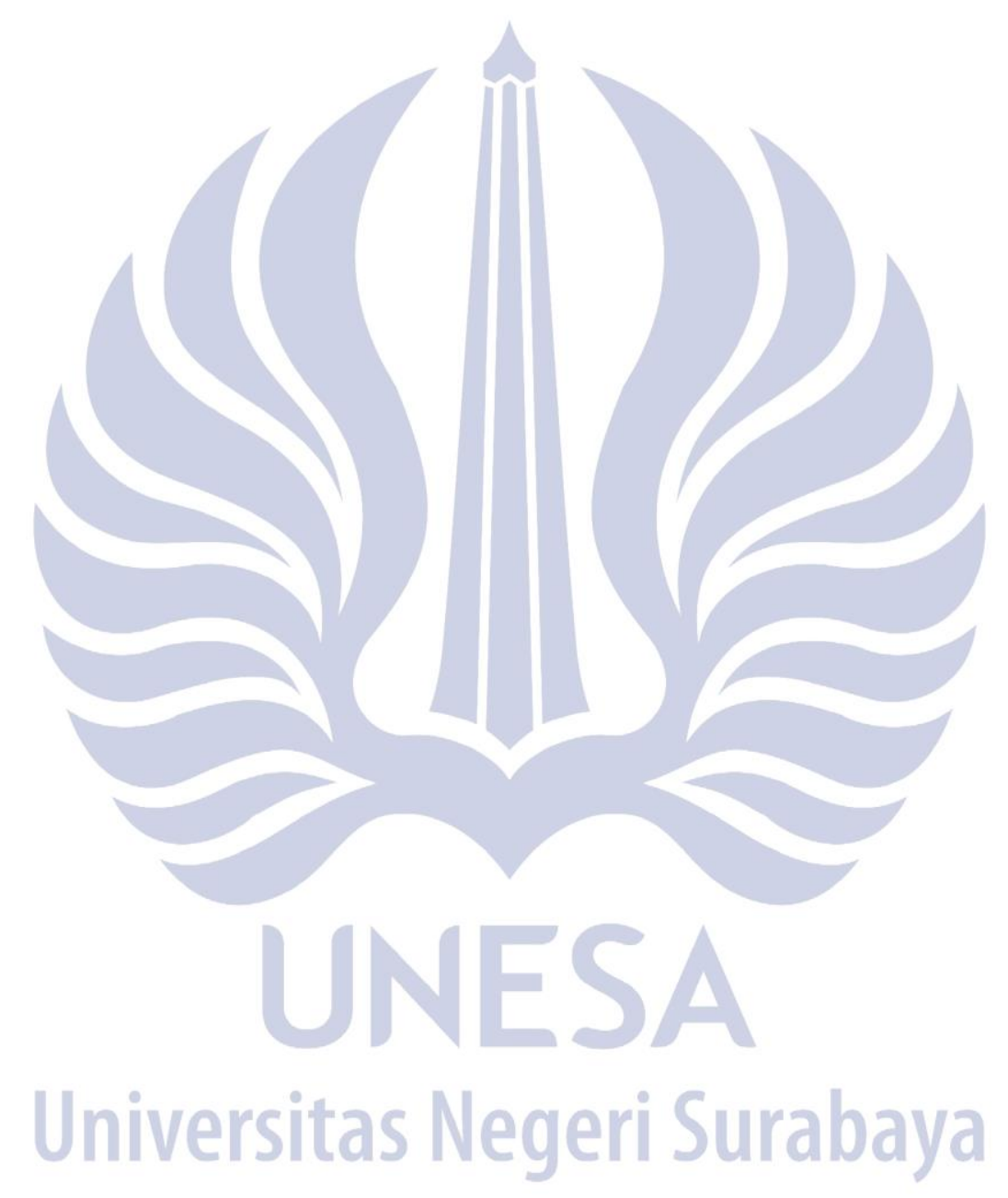

